\title{
Serogroup identification, phenotypic detection of hemolysis and extended spectrum beta-lactamases of Escherichia coli isolated from psittacine of illegal wildlife trade in Fortaleza, Brazil
}

\author{
[Identificação de sorogrupo e detecção fenotípica de betalactamase de espectro estendido e \\ produção de hemolisina em Escherichia coli isoladas de psitacídeos do tráfico de animais \\ silvestres em Fortaleza-CE]
}

\author{
E.S. Lopes, W.M. Cardoso, D.M. Nishi, R.V. Horn, Á.H. Albuquerque, S.V.G. Lima, A.J.F. Beleza, \\ F.C. Gaio, C.C. Carmo, M.N. Pascoal Filho, R.S.C. Teixeira \\ Universidade Estadual do Ceará - Fortaleza, CE
}

\begin{abstract}
This study aimed to identify serogroups of Escherichia coli important for human health in isolates from psittacine of illegal wildlife trade in Ceará State. In addition, hemolysis and production of Extended Spectrum Beta-Lactamases (ESBL) was assessed in the isolates. A total of 78 E. coli strains isolated from different Psittaciformes species from a wildlife rehabilitation center in Fortaleza, Brazil. The isolates used in this study were previously identified and stored. Serogroup identification was performed using polyvalent sera for EPEC (O55, O111, O119, O114, O125, O86, O126, O127, O128), EIEC (O136, O124) and EHEC (O157). ESBL detection was performed with double disk synergy method. For hemolysis detection, isolates were inoculated in blood agar base enriched with ovine blood. Only 31 $(39.7 \%)$ isolates were seropositive and the most frequent were O127, O114, O128 and O111. There was no agglutination for serogroups O55, O124, O136 or O157. Considering both seropositive and seronegative isolates, $9(11.5 \%)$ and $35(44.9 \%)$ presented hemolysis and ESBL production, respectively. In conclusion, the investigated psittacine from illegal wildlife trade hosted ESBL-producing E. coli strains and some belong to important serogroups often linked to severe human infections.
\end{abstract}

Keywords: escherichia coli, serogroups, ESBL, hemolysis

\section{RESUMO}

Este trabalho teve como objetivo identificar sorogrupos de E. coli importantes para a saúde humana, oriundos de psitacídeos provenientes do tráfico no estado do Ceará, assim como detectar atividade hemolítica e produção de betalactamase de espectro estendido (ESBL). Foram testadas 78 cepas de Escherichia coli provenientes de psitaciformes do Centro de Triagem de Animais Silvestres, Fortaleza, CE. Para a identificação dos sorogrupos, utilizaram-se soros polivalentes EPEC (O55, O111, O119, O114, O125, O86, O126, O127, O128), EIEC (O136, O124) e EHEC (O157). Para deteç̧ão de ESBL, as cepas foram submetidas ao método de aproximação de disco e, para a deteç̧ão de hemolisina, foram plaqueadas em ágar sangue base enriquecido com sangue de carneiro. No geral, 31 (39,7\%) das amostras foram soropositivas. Os sorogrupos mais frequentemente detectados foram O127, O114, O128 e O111. Não houve positividade para os sorogrupos O55, O124, O136 e O157. Considerando-se as amostras sororreagentes e não sororreagentes, observou-se que nove $(11,5 \%)$ e $35(44,9 \%)$ cepas de E. coli apresentaram produção de hemolisinas e de ESBL, respectivamente. Em conclusão, constatou-se que psitacídeos provenientes do tráfico de animais silvestres albergam cepas de E. coli produtoras de ESBL $e$ providas de importantes sorogrupos implicados em graves infecções humanas.

Palavras-chave: Escherichia coli, sorogrupos, ESBL, hemólise

\section{INTRODUCTION}

Important enterobacteria, such as Salmonella spp. and Escherichia coli, have been isolated from psittacine seized from illegal wildlife trade
(Marietto-Gonçalves et al., 2010). Therefore, the contact of these animals with humans or other animals may present a risk, considering that wild birds may transmit virulent or resistant pathogens (Bonnedahl et al., 2009; Saidenberg et al., 2012).

Recebido em 22 de agosto de 2016

Aceito em 4 de agosto de 2017

E-mail: elisangeladesouzalopes@hotmail.com 
Some E. coli strains that were identified as causative agents of intestinal disorders have been defined as a specific enteropathogenic pathotype (EPEC). These strains were initially diagnosed with serological tests and were associated with diarrhea in children (Regua et al., 1990). This denomination differentiates some of the pathogenic from commensal strains found in the human microbiota (Nataro and Kaper 1998). EPEC may host genes usually found in other diarrheagenic pathotypes, such as those encoding hemolysins (Magalhães et al., 2011). Pathogens with these characteristics may be detected with the hemolytic activity test, which has been important for initial analysis of virulence (Roy et al., 2006).

In addition to EPEC serogroups, others are known causative agents in humans. Serogroup O157, which is a part of enterohemorrhagic pathotype (EHEC) cause hemorrhagic colitis and hemolytic uremic syndrome in humans. When associated with flagellar antigen $\mathrm{H7}$, this is a severe and frequently lethal condition (Mittelstaedt and Carvalho 2006). However, despite the flagellar antigen $\mathrm{H} 7$, serogroup O157 is a severe pathogen to humans (Synge, 2000). A less frequent pathotype, but also related to human intestinal infections, is enteroinvasive Escherichia coli (EIEC), which often affects children with at least two years of age and adults (Martinez and Trabulsi, 2008).

In addition to hosting $E$. coli with virulence factors, antimicrobial resistance is a considerable problem concerning this microorganism, especially to beta-lactam antibiotics, which are frequently used in human and veterinary medicine (Bonnedahl et al., 2009). The investigation of bacterial resistance in wild birds from illegal wildlife trade is important not only due to the possibility of zoonotic transmission (Lopes et al., 2015), but also to the probable dissemination of these resistant microorganisms to the environment after reintroduction of infected and rehabilitated specimens (Dolejska et al., 2007).

In fact, studies relating the detection of virulence factors in the microbiota of wild birds are scarce, especially with victims of illegal wildlife trade. Therefore, this study aimed to identify serogroups of E. coli important for human health from psittacine of a local wild animals rehabilitation center in Fortaleza, Brazil. In addition, this study also aimed at assessing the presence of hemolytic activity and extended spectrum beta-lactamase production.

\section{MATERIAL AND METHODS}

A total of 78 strains of Escherichia coli previously isolated by Lopes et al. (2015) from Psittaciformes maintained in a local wild animal rehabilitation center in Fortaleza, Brazil, was used in this study. The experimental protocol was approved by the Animal Research Ethics Committee of Ceará State University (CEUA/UECE), protocol $n^{\circ}$ 127697942. Strains were maintained temporarily in nutrient agar and were reactivated to perform the tests. For serogroup identification, the polyvalent sera were used: EPEC (O55, O111, O119, O114, O125, O86, O126, O127, O128), EIEC (O136, O124) and (O157) (EHEC).

Serogroups were identified with rapid slide agglutination test following manufacturer's specifications. Briefly, a suspension with the strain was prepared with sterile buffered peptone water $(0.1 \%)$ and a drop was placed in a slide. Then, a drop of the polyvalent serum was added and gently homogenized with a result interpreted as positive when agglutination was observed and as negative in the absence of it. As a negative control, DH $\alpha$ E. coli strain was used and O157:H7 was used as a positive control.

Hemolysin production was assessed with the use of plates containing blood agar base enriched with ovine blood (5\%) inoculated with the E. coli strains incubated at $37^{\circ} \mathrm{C}$ for 24 horas. Then, plates were evaluated for the presence of partial or complete hemolysis.

E. coli isolates were tested for the production of extended spectrum beta-lactamases (ESBL) with the double disk synergy method according to Dhara et al. (2012) with modifications. Disk diffusion was performed in plates with MuellerHinton agar inoculated with a bacterial suspension adjusted to 0.5 turbidity in McFarland scale. Then, a disk containing amoxicillin with clavulanic acid $(30 \mu \mathrm{g})$ was placed in the center of the plate and surrounding in a distance of $30 \mathrm{~mm}$ from center to center from the central disk, the following were distributed: ceftazidime $(30 \mu \mathrm{g})$, ceftriaxone $(30 \mu \mathrm{g})$, cefepime $(30 \mu \mathrm{g})$ and aztreonam $(30 \mu \mathrm{g})$. ESBL production was positive when the inhibition zone was improved towards some of the cephalosporins or aztreonam, or even the appearance of an irregular inhibition zone (ghost zone) between the composed disk and one of the beta-lactam drugs. E. coli ATCC 25922 was used as a negative control and Klebsiella pneumoniae ATCC 700603 as a positive control. 


\section{RESULTS}

Agglutination was observed in 31 (39.7\%) out of 78 tested isolates. Most prevalent serogroup was O127 (11.5\%), followed by $\mathrm{O} 114$ and O128, both with a $6.4 \%$ frequency (Table 1). Among the twelve serogroups investigated, O55, O124, O136 and O157 were not identified. Strains isolated from Amazona aestiva and Eupsittula cactorum presented the most diversity of serogroups and elevated number of positive reactions.

Table 1. Absolute and relative frequencies of Escherichia coli serogroups isolated from psittacine seized from illegal wildlife trade in Ceará, Brazil

\begin{tabular}{|c|c|c|c|c|c|c|c|c|c|}
\hline \multirow[t]{2}{*}{ Avian species } & & \multicolumn{8}{|c|}{ Serogroups } \\
\hline & $\mathrm{n}$ & O86 & O111 & $\mathrm{O} 114$ & O119 & O125 & O126 & O127 & $\mathrm{O} 128$ \\
\hline $\begin{array}{l}\text { Eupsitulla } \\
\text { cactorum }\end{array}$ & 20 & - & $1(5.0 \%)$ & $1(5.0 \%)$ & $1(5.0 \%)$ & - & - & $4(20.0 \%)$ & - \\
\hline $\begin{array}{l}\text { Amazona } \\
\text { aestiva }\end{array}$ & 40 & $1(2.5 \%)$ & - & $3(7.5 \%)$ & $1(2.5 \%)$ & $2(5.0 \%)$ & $2(5.0 \%)$ & $3(7.5 \%)$ & $3(7.5 \%)$ \\
\hline $\begin{array}{l}\text { Amazona } \\
\text { amazonica }\end{array}$ & 9 & - & $2(22.2 \%)$ & - & - & $1(11.1 \%)$ & - & $1(11.1 \%)$ & - \\
\hline Ara ararauna & 4 & - & - & - & - & - & - & $1(25.0 \%)$ & \\
\hline $\begin{array}{c}\text { Anodorhynchus } \\
\text { hyacinthinus }\end{array}$ & 1 & - & - & - & - & - & - & - & $1(10 ., 0 \%)$ \\
\hline Ara severus & 1 & - & - & $1(100.0 \%)$ & - & - & - & - & - \\
\hline $\begin{array}{l}\text { Eupsittula } \\
\text { aurea }\end{array}$ & 2 & - & $1(50.0 \%)$ & - & - & - & - & - & - \\
\hline $\begin{array}{c}\text { Brotogeris } \\
\text { chiriri }\end{array}$ & 1 & - & - & - & - & - & - & - & $1(100.0 \%)$ \\
\hline Total & 78 & $1(1.3 \%)$ & $4(5.1 \%)$ & $5(6.4 \%)$ & $2(2.6 \%)$ & $3(3.8 \%)$ & $2(2.6 \%)$ & $9(11.5 \%)$ & $5(6.4 \%)$ \\
\hline
\end{tabular}

No strain was positive for serogroups O55, O124, O136 and O157.

Considering only the seropositive isolates, 4 $(5.1 \%)$ and $16(20.5 \%)$ presented hemolysis and ESBL production, respectively (Figure 1). Among the seronegative isolates, $5(6.4 \%)$ presented hemolytic activity and 19 (24.4\%) produced ESBL. In general, hemolysis rate was $11.5 \%$, while ESBL production rate was $44.9 \%$.

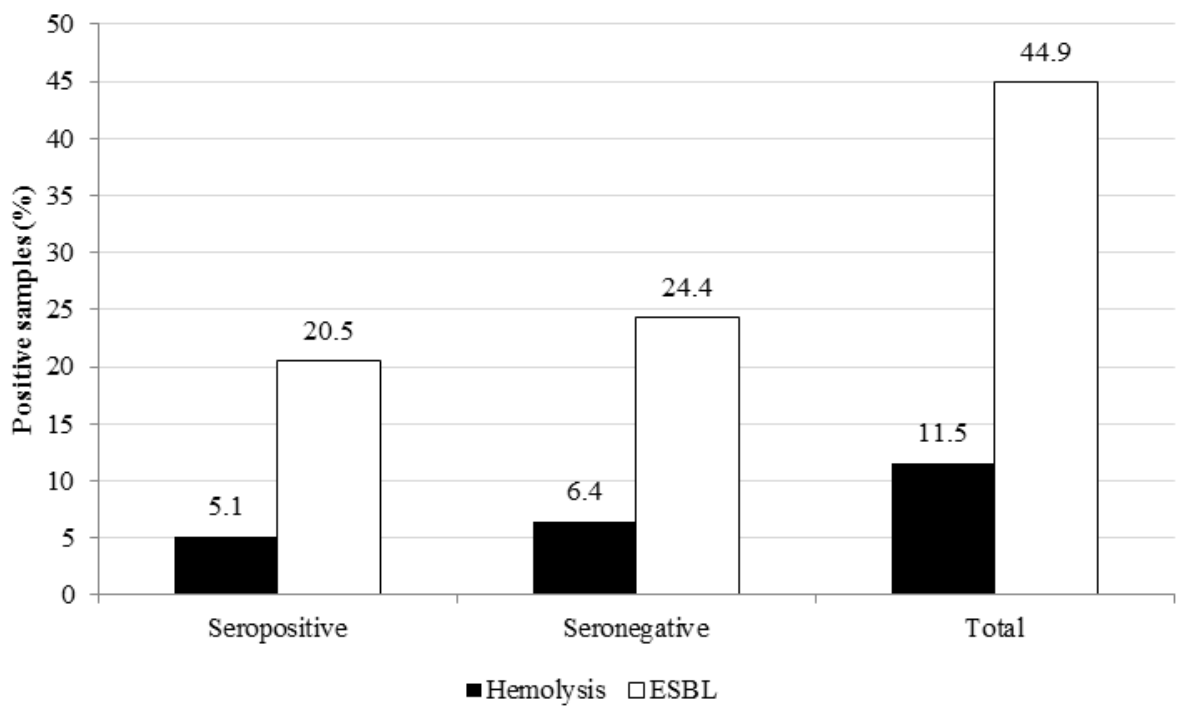

Figure 1. Percentage of seropositive and seronegative Escherichia coli strains producing hemolysis and ESBL isolated from psittacine seized from illegal wildlife trade.

Among the isolates that presented hemolysis, serogroups O86 $(\mathrm{n}=1), \mathrm{O} 127(\mathrm{n}=2)$ and O114 $(\mathrm{n}=1)$ were identified. ESBL-producing strains were positive for the following serogroups: $\mathrm{O} 111$ $(\mathrm{n}=1), \mathrm{O} 119(\mathrm{n}=2), \mathrm{O} 125 \quad(\mathrm{n}=3), \mathrm{O} 126 \quad(\mathrm{n}=1)$, O127 $(n=5)$, O128 (n=2), O86 (n=1). Only three isolates were positive for all tests and the serogroups were O86, O127 and O114. A total of 26 E. coli strains (33.3\%) were negative for ESBL-production, hemolysis and the investigated serogroups (Table 2). 
Table 2. Escherichia coli profile of psittacine surveyed for $\mathrm{O}$ serogroup, hemolysis and extended spectrum beta-lactamase (ESBL) production

\begin{tabular}{|c|c|c|c|}
\hline \multirow[t]{2}{*}{ Isolates (n) } & \multicolumn{3}{|c|}{ Bacterial profile } \\
\hline & Serogroups & Hemolysis & ESBL \\
\hline 1 & 086 & + & + \\
\hline 3 & $\mathrm{O} 111$ & - & - \\
\hline 1 & O111 & - & + \\
\hline 1 & $\mathrm{O} 114$ & - & + \\
\hline 3 & $\mathrm{O} 114$ & - & - \\
\hline 1 & $\mathrm{O} 114$ & + & + \\
\hline 1 & O119 & - & - \\
\hline 1 & O119 & - & + \\
\hline 3 & $\mathrm{O} 125$ & - & + \\
\hline 1 & $\mathrm{O} 126$ & - & - \\
\hline 1 & $\mathrm{O} 126$ & - & + \\
\hline 4 & $\mathrm{O} 127$ & - & + \\
\hline 3 & $\mathrm{O} 127$ & - & - \\
\hline 1 & $\mathrm{O} 127$ & + & - \\
\hline 1 & $\mathrm{O} 127$ & + & + \\
\hline 2 & $\mathrm{O} 128$ & - & + \\
\hline 3 & $\mathrm{O} 128$ & - & - \\
\hline 2 & NR & + & - \\
\hline 26 & NR & - & - \\
\hline 16 & NR & - & + \\
\hline 3 & NR & + & + \\
\hline 78 & $39.7 \% *$ & $11.5 \% *$ & $44.9 \% *$ \\
\hline
\end{tabular}

$\mathrm{NR}$ - Negative reaction to all of the sera used in this study.

* Positive percentage was calculated based on the total number of investigated strains $(\mathrm{n}=78)$.

\section{DISCUSSION}

The elevated variety and number of positive serogroups detected in strains from Amazona aestiva and Eupsittula cactorum may be explained by the fact that in the study in which they were isolated (Lopes et al., 2015), those were the main species found in the population.

The presence of these E. coli serogroups in the investigated birds may be associated with contact with humans during domiciliary captivity before being seized or during the period in which these animals are exposed to inappropriate conditions in their journey from capture in the wild until being apprehended by official authorities.

Most serogroups detected in this study (O111, O119, O114, O125, O86, O127, O126, O128) have been reported in breast-fed children (Regua et al., 1990; Oliva et al., 1997) in association with severe cases of acute diarrhea. Despite the fact that these serogroups have not been reported yet in psittacine, preventive measures should be applied to avoid severe problems, considering the importance of these microorganisms to human health and the possibility of transmission between birds and people.
In this study, serogroup O157 was not identified in any of the isolated samples. Studies demonstrate that the isolation frequency of $E$. coli strains from this serogroup is low. According to Coura et al. (2014), ruminants are considered the main reservoirs of EHEC with importance for human health. However, there are scarce reports of this serogroup in wild birds, which has been identified in seagulls (Wallace et al., 1997) and geese (Smith et al., 1998).

Some of the E. coli serogroups isolated in this study are not frequently reported in the scientific literature as pathogens for birds, as is the case of O128. In our study, this serogroup was identified in three Amazona aestiva, one Anodorhynchus hyacinthinus and one Brotogeris chiriri, which did not present any clinical signs of disease. Similar to this study, free-living pigeons in Würzburg, Germany, were positive for E. coli O128 and clinical signs were not reported (Schmidt et al., 2000).

However, a study performed with eight E. coli strains isolated from diseased parrots admitted for treatment in the clinic of the University of São Paulo, Brazil, identified one isolate from serogroup $\mathrm{O} 128$ in a liver sample from a bird that presented clinical signs of avian colibacilosis 
and died (Knöbl et al., 2008). In addition, a study performed with birds that presented enteritis and septicemia revealed that one psittacine, out of 14 carcasses submitted to necropsy, presented an $E$. coli from serogroup $\mathrm{O} 128$ in a liver sample (Knöbl et al., 2011).

Serogroup O86 have also been reported causing disease and mortality in wild birds (Foster et al., 1998). However, the isolation of this serogroup in a single bird (Amazona aestiva) in this study reveals that psittacine may act as asymptomatic hosts. This serogroup, in association with antigen $\mathrm{K} 61$, have been detected in liver, intestine and caeca of dead free-living passerines in Scotland. Therefore, researchers reported that free-living birds might play a role as reservoirs of these microorganisms for production and pet animals, in addition to the possibility of zoonotic problems derived from practices that that promote an agglomeration of great numbers of passerines in urban environments (La Ragione et al., 2002).

Considering all of the analyzed bacteria, the percentage of positive samples with hemolytic activity was considerably low in comparison to a study performed in feces samples of Psittaciformes seized and in rehabilitation before reintroduction in Botucatu, Brazil (MariettoGonçalves et al., 2010). In this occasion, from a total of $89 \mathrm{E}$. coli isolates, $70.6 \%$ produced hemolysis. Considering this virulence factor, $E$. coli isolated from birds in the wildlife rehabilitation center in Fortaleza, Brazil, sampled in this study may present a lesser risk to humans and other animals. Despite the low positive rate found with the hemolysin production test, the possible virulence of these microorganisms cannot be discarded, considering that several serogroups often involved in human cases have been identified in this study.

ESBL production in members from the Enterobacteriaceae family, specifically E. coli, is serious concern in several countries, due to the frequent implications in human infections (Costa et al., 2006). ESBL-producing E. coli strains is frequently reported in production animals (Briñas et al., 2003; Shiraki et al., 2004; Briñas et al., 2005), in pet and wild animals in Portugal, Italy and France (Carattoli et al., 2005, Costa et al., 2006; Bonnedahl et al., 2009). This problem has not been reported yet with psittacine. However, ESBL-producing E. coli strains have been isolated from wild and aquatic birds (Literak et al., 2010; Pinto et al., 2010).
Despite the commensal characteristic, Escherichia coli is frequently implicated in human and animal infections, especially production animals, which are more frequently exposed to antibiotics, such as beta-lactams. Hence, their possible contact with wild animals may be related to the dissemination of these microorganisms to the wildlife (Guenther et al., 2011). However, the antimicrobial resistance identified in this study may be related to direct and inappropriate use of antibiotics with therapeutic or preventive intent. Therefore, detecting ESBL-producing strains in psittacine from illegal wildlife trade in Ceará is worrying, considering that seized birds are in some way affected, direct or indirectly by inadequate use of antibiotics.

Reintroduction of animals to nature is the solution chosen by the official authorities in Brazil. However, this option may have a potential risk for the environment. Monitoring ESBL-producing E. coli strains of clinic or commensal origin must be performed in both humans and animals in order to observe the evolution and analyze factors that contribute to the selection and propagation of these resistance mechanisms (Briñas et al., 2005).

In conclusion, psittacine from illegal wildlife trade may host ESBL-producing E. coli strains of different serogroups, in which some are often implicated in severe human infections. This study revealed the occurrence of some E. coli serogroups not yet previously reported in other studies involving wild birds and, more specifically, members of the Psittacidae family. Therefore, more studies with other serogroups of veterinary and human medicine importance should be performed.

\section{ACKNOWLEDGMENTS}

The authors thank the Conselho Nacional de Desenvolvimento Científico e Tecnológico (CNPq), Centro de Triagem de Animais Silvestres de Fortaleza (CETAS) and Laboratório de Estudos Ornitológicos (LABEO) for all the support in this study.

\section{REFERÊNCIAS}

BONNEDAHL, J.; DROBNI, M.; GAUTHIERCLERC, M. et al. Dissemination of Escherichia coli with CTX-M type ESBL between human and Yellow-Legged Gulls in the South of France. Plos ONE., v.4, p.1-6, 2009. 
BRIÑAS, L.; MORENO, M.A.; TESHAGER, T. et al. Monitoring and characterization of Extended-spectrum - lactamases in Escherichia coli strains from healthy and sick animals in Spain in 2003. Antimicrob. Agents Chemother., v.49, p.1262-1264, 2005.

BRIÑAS, L.; MORENO, M.A.; ZARAZAGA, M. et al. Detection of CMY-2, CTX-M-14, and SHV-12 -Lactamases in Escherichia coli fecalsample isolates from healthy chickens. Antimicrob. Agents Chemother., v.47, p.20562058, 2003.

CARATTOLI, A.; LOVARI, S.; FRANCO, A. et al. Extended-Spectrum $\beta$-lactamases in Escherichia coli isolated from dogs and cats in Rome, Italy, from 2001 to 2003. Antimicrob. Agents Chemother., v.49, p.833-835, 2005.

COSTA, D.; POETA, P.; SÁENZ, Y. et al. Detection of Escherichia coli harbouring extended-spectrum $\beta$-lactamases of the CTX-M, TEM and SHV classes in fecal samples of wild animals in Portugal. Antimicrob. Agents Chemother., v.58, p.1311-1312, 2006.

COURA, F.M.; ANDREY, P.L.; MARCOS, B.H. Patotipos de Escherichia coli causadores de diarreia em bezerros: uma atualização. Pesqui. Vet. Bras., v.34, p.811-818, 2014.

DHARA, M.; DISHA, P.; SACHIN, P. et al. Comparison of various methods for the detection of extended spectrum beta lactamase in Klebsiella pneumoniae isolated from neonatal intensive care unit, ahmedabad. Natl. J. Med. Res., v.2, p.348-353, 2012.

DOLEJSKA, M.; CIZEK, A.; LITERAK, I. High prevalence of antimicrobial-resistant genes and integrons in Escherichia coli isolates from Black-headed Gulls in the Czech Republic. J. Appl. Microbiol., v.103, p.11-19, 2007.

FOSTER, G.; ROSS, H.M.; PENNYCOTT, T.W. et al. Isolation of Escherichia coli O86:K61 producing cyto-lethal distending toxin from wild birds of the finch Family. Lett. Appl. Microbiol., v.26, p.395-398,1998.

GUENTHER, S.; EWERS, C.; WIELER, L.H. Extended-spectrum betalactamase producing $E$. Coli in wildlife, yet another form of environmental pollution? Fron. Microbiol., v.2, p,1-13, 2011.

KNÖBL, T.; GODOY, S.N.; MATUSHIMA, E.R. et al. Caracterização molecular dos fatores de virulência de estirpes de Escherichia coli isoladas de papagaios com colibacilose aviária. Braz. J. Vet. Res. Anim. Sci., v.45, p.54-60, 2008.
KNÖBL, T.; SAIDENBERG, A.B.S.; MORENO, A.M. et al. Serogroups and virulence genes of Escherichia coli isolated from psittacine birds. Pesqui. Vet. Bras., v.31, p.916-921, 2011.

LA RAGIONE, R.M.; MCLAREN, I.M.; FOSTER, G. et al. Phenotypic and genotypic characterization of avian Escherichia coli O86:K61 isolates possessing a Gamma-like intimin. Appl. Environ. Microbiol., v.68, p.49324942, 2002.

LITERAK, I.; DOLEJSKA, M.; JANOSZOWSKA, D. et al. Antibiotic-resistant Escherichia coli bacteria, including strains with genes encoding the extended-spectrum betalactamase and QnrS, in waterbirds on the Baltic Sea Coast of Poland. Appl. Environ. Microbiol., v.76, p.8126-8134, 2010.

LOPES, E.S.; MACIEL, W.C.; ALBUQUERQUE, A.H. et al. Prevalence and Antimicrobial resistance profile of Enterobacteria isolated from Psittaciformes of illegal wildlife trade. Acta Sci. Vet., v.43, p.1-9, 2015.

MAGALHÃES, C.A.; ROSSATO, S.S.; BARBOSA, A.S. et al. The ability of haemolysins expressed by atypical enteropathogenic Escherichia coli to bind to extracellular matrix componentes. Mem. Inst. Oswaldo Cruz., v.106, p.146-152, 2011.

MARIETTO, G.A.G.; ALMEIDA, S.M.; LIMA, E.T. et al. Detecção de Escherichia coli e Salmonella sp. em microbiota intestinal de Psittaciformes em fase de reabilitação para soltura. Braz. J. Vet. Res. Anim. Sci., v.47, p.185189, 2010.

MARTINEZ, M.B.; TRABULSI, L.R. Enterobacteriaceae. In: TRABULSI, L.R.; ALTHERTHUM, F. Microbiologia. 5ed. São Paulo: Atheneu, 2008, p.267-279.

MITTELSTAEDT, S.; CARVALHO, V.M. Escherichia coli enterohemorrágica (EHEC) O157:H7-revisão. Rev. Inst. Cienc Saúde, v.24, p.175-182, 2006.

NATARO, J.P.; KAPER, J.B. Diarrheagenic Escherichia coli. Clin. Microbiol. Rev., v.11, p.142-201, 1998.

OLIVA, C.A.G.; SCALETSKY, I.; MORAIS, M.B. et al. Diarreia aguda grave associada à Escherichia coli enteropatogênica clássica (EPEC): características clínicas e enteropatogênica clássica (EPEC): características clínicas e perdas fecais em lactentes hospitalizados. Rev. Assoc. Med. Bras., v.43, p.283-289, 1997. 
PINTO, L.; RADHOUANI, H.; COELHO, C. et al. Genetic detection of extended-spectrum betalactamase-containing Escherichia coli isolates from birds of prey from Serra da Estrela Natural Reserve in Portugal. Appl. Environ. Microbiol., v.76, p.4118-4120, 2010.

REGUA, A.H.; BRAVO, V.L.R.; LEAL, M.C. et al. Epidemiological survey of the enteropathogenic Escherichia coli isolated from children with Diarrhoea. J. Trop. Pediatr., v.36, p.176-179, 1990.

ROY, P.; PURUSHOTHAMAN, V.; KOTEESWARAN, A. et al. Isolation, characterization, and antimicrobial drug resistance pattern of Escherichia coli isolated from japonese quail and their environment. $J$. Appl. Poult. Res., v.15, p.442-446, 2006.

SAIDENBERG A.B.; TEIXEIRA R.H.F.; GUEDES N.M.R. et al. Molecular detection of enteropathogenic Escherichia coli in asymptomatic captive psittacines. Pesqui. Vet. Bras., v.32, p.922-926, 2012.
SCHMIDT, H.; SCHEEF, J.; MORABITO, S. et al., A new shiga toxin 2 variant (Stx2f) from Escherichia coli isolated from pigeons. Appl. Environ. Microbiol., v.66, p.1205-1208, 2000.

SHIRAKI, Y.; SHIBATA, N.; YOHEI, D. et al. Escherichia coli producing CTX-M-2 $\beta$ lactamase in cattle, Japan. Emerg. Infect Dis., v.10, p.69-75, 2004.

SMITH, H.R.; ROWE, B.; ADAK, G.K. et al. Shiga toxin (verocytotoxin-producing) Escherichia coli in the United Kingdom, p 49-58 1998. In. KAPER, J.B.; O'BRIEN, A.D. (Eds.). Escherichia coli O157:H7 and other Shiga toxinproducing Escherichia coli strains. Washington: ASM Press, 1998.

SYNGE, B.A. Verocytotoxin-producing Escherichia coli: a veterinary view. J. Appl. Microbiol., v.88, p.318-378, 2000.

WALLACE, J.S.; CHEASTY, T.; JONES, K. Isolation of verocytotoxinproducing Escherichia coli $\mathrm{O} 157$ from wild birds. J. Appl. Microbiol., v.82, p.99-404, 1997. 